pathogen. Prescribing sulphonamides in pregnancy has been criticized because they interfere with the binding of bilirubin to serum proteins, thereby increasing the risk of kernicterus, ${ }^{11}$ but provided they are avoided during the last month this risk appears to be negligible. Geographical variations in the prevalence of sulphonamide-resistant strains of $E$. coli exist. In this issue of the B.M.F. Drs. J. D. Williams and Edna K. Smith record at page 651 that $34 \%$ of the coliform organisms isolated from bacteriuric antenatal patients in the Birmingham area show sulphonamide resistance in contrast to only $13 \%$ of the strains isolated from similar patients in London. ${ }^{12}$ This observation accounts for the low cure rate $(55 \%)$ from sulphonamide treatment of pregnant bacteriuric women in Birmingham against the much higher one $(88 \%)$ observed in London. ${ }^{13}$ In those areas where sulphonamide resistance among coliforms is common, short courses of the "second-line" drugs such as ampicillin, nitrofurantoin, cephalexin, or nalidixic acid are indicated as initial treatment.

The place of sulphonamide-trimethoprim combinations in the primary treatment of bacteriuria in pregnant women needs further evaluation. Preliminary studies ${ }^{14}$ suggest that a very high cure rate of pregnancy bacteriuria can be obtained, but reports of the teratogenic effects of high doses of trimethoprim in rats make it inadvisable to use this extremely effective combination in early pregnancy. ${ }^{15}$ Tetracycline should not be given for the treatment of bacteriuria in pregnancy because it interferes with bone development in premature infants ${ }^{16}$ and produces discolouration of the primary dentition. ${ }^{17}$

The essence of good treatment is good follow-up, since infections of the urinary tract frequently recur. Quantitative bacterial cultures of the urine should be performed at each follow-up visit, and these visits should be at monthly or shorter intervals. Each recurrence should be treated with a short course of one of the "second-line" drugs mentioned above, the choice of drug being determined by the results of in-vitro sensitivity tests. Scrupulous follow-up is facilitated by the use of "dip-slides"18 or glucose oxidase test strips. ${ }^{19}$ These methods enable prompt detection and treatment of recurrent infection without the need for frequent attendances at clinics.

Clearly a high degree of co-operation from the patient is required if urinary tract infection is managed in the manner

'Asscher, A. W., The Early Diagnosis of Urinary Tract Infection, London,

Office of Health Economics, 1970.
${ }^{2}$ Kass, E. H., Archives of Internal Medicine, 1960, 105, 194.

'Elder, H. A., and Kass, E. H., in Progress in Pyelonephritis, ed. E. H. Kass, p. 81. Philadelphia, F. A. Davis, 1965.

'Williams, G. L., Campbell, H., and Davies, K. J., British Medical fournal, 1969, 3, 212.

${ }^{5}$ Williams, J. D., et al., in Urinary Tract Infection, ed. F. O'Grady and W. Brumfit, p. 160 . London, Oxford University Press, 1968.

'Gower, P. E., in Urinary Tract Infection, ed. F. O'Grady and W. Brumfitt, p. 235. London, Oxford University Press, 1968.

'Grüneberg, R. N., Leigh, D. A., and Brumfitt, W., Lancet, 1969, 2, 1.

'Williams, D. M., Wimpenny, J., and Asscher, A.' W., Lancet, 1968, 2 , 1058.

'Williams, J. D., Brumfitt, W., Leigh, D. A., and Percival, A., Lancet, 1965, 1,831 .

${ }^{10}$ Brumfitt, W., and Percival, A., British fournal of Clinical Practice, 1962, $16,253$.

11Odell, G. B., fournal of Clinical Investigation, 1959, 38, 823.

12Williams, J. D., and Leigh, D. A., British fournal of Clinical Practice, 1966,

20, 177.
${ }^{13}$ Grüneberg, R. N., and Brumfitt, W., British Medical fournal, 1967, 3, 649.

${ }^{13}$ Grüneberg, R. N., and Brumfitt, W., British Medical fournal, 1967, 3, 649.
1'Brumfitt, W., and Reeves, D. S., fournal of Infectious Diseases, 1969, 120, 61.

${ }_{15}^{15}$ British Medical Fournal, 1969, 3, 578.

19Cohlan, S. Q., Bevelander, G., and Tiamsic, T., American fournal of Diseases of Children, 1963, 105, 453.

${ }^{1}$ Davies, P. A., Little, K., and Aherne, W., Lancet, 1962, 1, 743.

${ }^{18}$ Guttman, D., in Abstracts of the 4th International Congress of Nephrology, 1969, vol. 1, p. 382.

${ }^{10}$ Shersten, B., Dahlqvist, A., Fritz, H., Köhler, L., and Westlund, L., Fournal of the American Medical Association, 1968, 204, 205.

${ }^{20}$ Beveridge, J., Harris, M., Wise, G., and Stevens, L., Lancet, 1964, 2, 593. outlined here, but it is not always forthcoming. In the management of the non-cooperative woman with bacteriuria during pregnancy there is a place for single-dose treatment with one of the ultra-long-acting sulphonamides. In a London community in which the prevalent coliform strains were sensitive to sulphonamides, a single oral dose of $2 \mathrm{~g}$. of sulfadoxine gave an $88 \%$ cure rate among the willing volunteers who took part in the trial. ${ }^{13}$ Naturally it is impossible to study cure rates among non-attenders, but it has been assumed that their response to single-dose treatment is equally satisfactory. In their article this week Drs. Williams and Smith show that the cure rates after single (2-g.) doses of the ultra-long-acting sulphonamides sulfadoxone and sulfametapyrazine were disappointingly low (55 and 66\% respectively). This finding was attributed to the high prevalence of sulphonamide-resistant coliforms in their locality. The highest cure rate $(77 \%)$ was obtained when a single dose of sulfametapyrazine was combined with an intramuscular injection of $1 \mathrm{~g}$. of streptomycin. However, the difference between the cure rates produced by the combined treatment and that produced by sulfametapyrazine alone was not significant. On the evidence presented no case can therefore be made for combining streptomycin with sulfametapyrazine. Fears that long-acting sulphonamides are apt to produce the Stevens-Johnson syndrome ${ }^{20}$ cannot be entirely dispelled, and in view of this it would seem wise to reserve single-dose treatment with ultra-long-acting sulphonamides for those patients who are likely to default from follow-up. Certainly single-dose treatment should not be used merely for the sake of convenience so long as there is any doubt about the toxicity of these drugs.

\section{Professional Discipline}

Since its first, modest excursion into public relations by way of a pamphlet" (the "blue pamphlet") in 1963, the General Medical Council cannot be accused of being uninformative about what it does. The pamphlet has been kept up to date by further editions, the latest in January this year, and in April a leaflet ${ }^{2}$ on the general work of the council was added to the information available to members of the public or the profession interested in the body that functions for their mutual benefit. Now changes in the G.M.C.'s disciplinary powers effected by the Medical Act, 1969, make a revised version of the blue pamphlet necessary, and it is to be published in January under the title "Professional Discipline."

With availability since April of the leaflet ${ }^{2}$ on the council's work generally, the new pamphlet will deal only with disciplinary matters. From what the President said in his recent address $^{3}$ to the G.M.C. it is clear that the pamphlet will aim to meet some recent criticisms of the council in its disciplinary work-criticisms which the President himself took some trouble to answer. For example, by placing a disregard of personal responsibilities to patients at the top of the list of forms of professional misconduct which may lead to disciplinary proceedings, the new pamphlet emphasizes the gravity with which the council regards such offences and counters criticism that there has been insufficient concern with them. Likewise adultery or other improper conduct or

\footnotetext{
1 General Medical Council, Functions, Procedure and Furisdiction, 1963. Office of the Council, 44 Hallam Street, London W IN 6AE.

2 General Medical Council, What it is and What it Does, April 1970. Office of the Council, 44 Hallam Street, London W1N 6AE.

3 British Medical fournal Supplement, 1970, 3, 53.

4 British Medical fournal, 1970, 4, 317.
} 
association with a patient or member of a patient's family has been demoted from second place to fifth, but it is stressed that the professional sin is an abuse by a doctor of his professional position in order to further an improper relationship or adultery and not the adultery itself. The G.M.C.'s reasons for objecting to advertising by doctors are clearly put as being "incompatible with the principles which should govern relations between members of the profession. . . . A doctor who was successful at achieving publicity might not in fact be the most appropriate doctor for a patient to consult." This is in sharp contrast with the Monopolies Commission's support for more advertising within the professions. ${ }^{4}$

However, an offence in the eyes of the G.M.C. is not measured by its position in a league table but by whether it amounts to "serious professional misconduct"- the words which the Medical Act of 1969 substituted for the previous "infamous conduct in a professional respect." The disciplinary jurisdiction of the council now enables its Disciplinary Committee to erase from the Register or to suspend from registration for a period not exceeding 12 months the name of a doctor who has been convicted of a criminal offence or is judged guilty of serious professional misconduct. A conviction by a criminal court has to be accepted by the Disciplinary Committee as conclusive evidence of guilt; and it is how the criminal offence affects the doctor's fitness to practise that the committee must judge. Findings of National Health Service disciplinary authorities do not count as convictions, but a charge of serious professional misconduct may arise from conduct which has been the subject of proceedings within the N.H.S. Whether any particular conduct amounts to serious professional misconduct is a matter which the Disciplinary Committee has to decide after hearing the evidence in each individual case. This is a function that a committee predominantly professional in composition is eminently fitted to perform, and the right of self-government in this respect which doctors so successfully gained in 1858 should be jealously preserved for all time by their successors.

The report in the Supplement of the recent session of the Disciplinary Committee suggests that the new penalty of suspension from registration is likely to be used in many cases. It has the virtue of being for a fixed period and, as with erasure, it is subject to appeal. Its great merit as a measure for the protection of the public is that it becomes operative immediately. Like the preceding pamphlets, "Professional Discipline" will probably be intended primarily for recently qualified and provisionally qualified doctors. But it should be read by all doctors, and the profession would then be better informed about the disciplinary work of its ruling body

\section{Local Anaesthetics Containing Vasoconstrictors}

Local anaesthetics such as lignocaine have only a brief duration of action in most tissues because they are quickly removed and diluted by blood flow. Addition of a drug such as adrenaline or noradrenaline to the anaesthetic solution constricts the blood vessels and prolongs the action. A dental anaesthetic given with $2 \%$ lignocaine hydrochloride lasts about 15 minutes, but the addition of $1: 80,000$ adrenaline or noradrenaline prolongs the effect to an hour and a half or more. Vasoconstriction not only prolongs anaesthesia but also prevents rapid absorption of the anaesthetic drug into the systemic circulation. Anaesthetics such as lignocaine have an action on membranes in many tissues including the heart, and in large doses depress myocardial contractility.

The main hazard of local anaesthetics containing vasoconstrictors lies in their use in tissues with a restricted circulation. Severe tissue necrosis has followed the use of local anaesthetics containing adrenaline or noradrenaline to produce a ring block in a finger or toe or in operations on the penis or the ear. This is a special risk in casualty departments, and it is wise to issue only plain local anaesthetics, which should have sufficient duration of action for simple suturing procedures.

There has been concern that local anaesthetics containing adrenaline or noradrenaline might interact dangerously with other drugs such as monoamine oxidase inhibitors, hypotensive agents, tricyclic antidepressants, and volatile anaesthetics such as halothane and cyclopropane. In fact there is no special risk in patients on monoamine oxidase inhibitors. Inactivation of circulating catecholamines depends chiefly on uptake into nerves and tissues and not upon metabolism. Patients taking these drugs have a normal response to intravenous doses of adrenaline and noradrenaline, ${ }^{12}$ though they are at risk from a pressor crisis if noradrenaline-releasing agents such as tyramine are used. Drugs that blockade adrenergic neurones increase sensitivity to circulating catecholamines several-fold, as do the tricyclic antidepressants such as imipramine, which block the uptake of adrenaline and noradrenaline into nerves. ${ }^{34}$ In each case potentiation of the effect of the catecholamines is likely to be important only if a dose is injected intravenously. Chloroform, halothane, trichlorethylene, cyclopropane, and hypothermia sensitize the myocardium to circulating catecholamines and increase the risk of arrhythmia. It is unlikely and undesirable that a patient should have a general anaesthetic with one of these drugs if he has received a large amount of local anaesthetic containing adrenaline immediately beforehand. However, if this is unavoidable and an arrhythmia develops it ought to respond to a small dose of intravenous propranolol ${ }^{5}$ b or practolol. ${ }^{7}$

The risk depends on the dose of adrenaline or noradrenaline in the solution. Dental cartridges are commonly of $\mathbf{2 \cdot 2}$ or $1.8 \mathrm{ml}$. capacity and contain 1:80,000 adrenaline or noradrenaline. Thus the dose of the catecholamine is about $25 \mu \mathrm{g}$. If this is absorbed into the circulation over two hours or more it would not be expected to exert any pharmacological effect in any of these situations. Should it be injected directly into a vein as a "bolus" a substantial effect would occur, but it would be of brief duration. The risk of rapid absorption is greatest in very vascular tissue and in inflammation. In the case of solutions containing adrenaline there would be a risk of cardiac arrhythmia, while those containing noradrenaline would cause a greater rise in blood pressure. The very small risk of direct intravenous injection appears acceptable in view of the much more satisfactory anaesthesia obtained with the mixtures containing vasoconstrictors.

The amount of adrenaline or noradrenaline in ampoules supplied for local anaesthesia in other situations has been

\footnotetext{
1 Horwitz, D., Goldberg, L. I., and Sjoerdsma, A., fournal of Laboratory and Clinical Medicine, 1966, 56, 747.

2 Elis, J., Laurence, D. R., Mattie, H., and Prichard, B. N. C., British Medical fournal, 1967, 2, 75.

3 Dollery, C. T., Harington, M., and Hodge, J. V., British Heart Fournal, $1963,25,670$

4 Iversen, L. L., The Uptake and Storage of Noradrenaline in Sympathetic Nerves. London, Cambridge University Press, 1967.

5 Vickers, M. D., Prescribers' fournal, 1968, 8, 75.

' Johnstone, M., British fournal of Anaesthesia, 1966, 38, 516.
} 